\title{
1 \\ Alliances, Nuclear Weapons and Escalation
}

\author{
Stephan Frühling and Andrew O’Neil
}

As great power competition once again assumes a central place in international relations, alliances have taken on renewed importance in the security calculations of Australia and other US allies in the Indo-Pacific and Europe. Deterrence of an attack on allies is a core function of US alliances, as are mechanisms through which states seek to manage the risk of escalation-the movement through increasing intensity of conflict up to, in the extreme, global nuclear war. ${ }^{1}$ Alliances seek to prevent escalation in the form of an attack on its members through strategies of deterrence and extended deterrence that are themselves predicated on credible threats of escalation. Nuclear weapons are central to deterrence and escalation considerations and form a key component of America's strategic toolkit to reassure Japan, South Korea and Australia in the Indo-Pacific, as well as North Atlantic Treaty Organization (NATO) allies in the Euro-Atlantic.

However, allies cannot afford to be passive actors in their interactions with Washington. They need to prepare for and seek to manage escalation in a broader geostrategic, technological and political context that shapes the ability of alliances to adapt to a new security environment. While the challenge of great power competition is acute at both ends of Eurasia, adversary threats, geography and the institutional context of US

1 See Kerry M. Kartchner and Michael S. Gerson, 'Escalation to Limited Nuclear War in the 21st Century', in On Limited Nuclear War in the 21st Century, ed. Jeffrey Larsen and Kerry M. Kartchner (Stanford: Stanford University Press, 2014), 144-71. 
alliances differ. This volume brings together contributors from Europe, North-East Asia, the United States and Australia to better understand these challenges, identify commonalities and differences across regions, and pinpoint ways to collectively manage nuclear deterrence in twenty-firstcentury alliances. It focuses on nuclear deterrence in the Indo-Pacific and strategic competition between the US and China; the role of non-nuclear US allies in the Indo-Pacific and Europe in supporting US extended nuclear deterrence; political-military challenges in alliance plans for escalation; allied perspectives on the consequences of new non-nuclear capabilities, including cyber and hypersonic weapons, for deterrence and strategic stability; and lessons on how the US and allied nations can better engage their respective publics on questions relating to nuclear deterrence.

\section{Alliances, Escalation and Nuclear Weapons}

How to manage escalation is an inherently political question. The costs and benefits of support in case of attack and of achieving security against specific challenges will differ between allies. The credibility of extended deterrence threats rests on the commitment of certain allies, especially the US, to provide security to other allies who find themselves under more immediate threat. The asymmetric nature of an extended deterrence relationship thus creates anxieties of abandonment on the part of the threatened ally and fears of entrapment by all allies in conflicts in which they have little direct stake. For deterrence to be effective, allies nonetheless have to find ways to agree and credibly commit to what they are willing to do for each other.

Nowhere is this more important than in relation to the role of US nuclear weapons in America's alliances. While some US allies have previously expressed sympathy for the Treaty on the Prohibition of Nuclear Weapons (TPNW), none today is willing to sign it, as their focus has turned to the challenge of managing escalation in potential great power conflicts in Europe and the Indo-Pacific. Moscow's penchant for nuclear sabre-rattling in crises with NATO and Ukraine, Beijing's ambitious nuclear force modernisation, North Korea's development of a thermonuclear and intercontinental range arsenal, and the development of new capabilities- 
including hypersonic missiles designed to confer escalation advantage over the US and its allies in regional conflicts-have all roused nuclear strategy from its post-Cold War hibernation. From 2011, the Obama administration established extended deterrence dialogues with North-East Asian treaty allies, Japan and South Korea, in response to growing concerns about North Korea and China. Since 2014, the NATO alliance has paid far greater institutional and political attention to the strategic role of its nuclear forces, and to the possibilities of escalation more generally after the end of the Intermediate-Range Nuclear Forces (INF) Treaty. Under the Trump administration, US nuclear policy was notable for how little controversy it attracted among US allies, despite the administration's decision to introduce the first new (low-yield) warhead variants since the end of the Cold War.

However, the existential dependence of US allies on decisions taken in Washington about US nuclear strategy has been a constant element in the history of US alliances, and key to grasping their inherent tensions: from US Secretary of Defense Robert McNamara’s challenge to NATO's nuclear strategy of massive retaliation in the early 1960s, to concerns about USSoviet arms control undermining the security of Western Europe in the 1970s and the late 1980s, to President Obama's declared commitment to reducing the role of nuclear weapons in US defence posture in the face of rising nuclear threats to North-East Asian allies. Throughout the Cold War, arguments about nuclear strategy were staple fare for official and academic debates, especially regarding the role of nuclear weapons in deterrence. How to interpret and implement the concept of flexible response after its adoption in 1967 was the subject of often acrimonious debate in NATO, as allies sought to balance fears of abandonment, entrapment and a Soviet Union that threatened them all, but in different ways depending on their geographical position. In Asia, forward-based US nuclear forces on the Korean Peninsula were a central element in deterring North Korea until their withdrawal in 1992, and Japan carefully balanced its public aversion to nuclear weapons with practical support for the operation of US nuclear forces as a deterrent against the Soviet Union and China. In Australia, the role of the 'joint facilities' in US nuclear operations was a central element of the alliance in the second half of the Cold War. 


\section{Managing Escalation in the Indo-Pacific and Euro-Atlantic Areas}

At the 2021 Munich Security Conference, President Biden declared that 'America is back', and that 'the United States is determined ... to earn back our position of trusted leadership. ${ }^{2}$ However, while it is clear that public division and disagreement among allies about how to manage escalation and deter threats are undesirable, the US and its allies still have a long way to go in either the Indo-Pacific or the Euro-Atlantic areas to develop viable and commonly accepted political-military strategies for the new era of great power competition. ${ }^{3}$ Significant differences remain between the challenges of escalation at either end of Eurasia, but the basic problemhow US allies can achieve political agreement on credible threats of military escalation, including through the use of nuclear weapons, to deter attacks by nuclear-armed powers_-remains the same. Hence, the value of exchanging ideas between the Indo-Pacific and Euro-Atlantic areas is also far greater than it has been in the past.

In the 1980s, a US official reportedly observed that exchanges between NATO and Japan throughout the INF negotiations had 'taught the Japanese to speak German'. ${ }^{4}$ The Reagan administration's decision to abrogate US obligations towards ANZUS (Australia, New Zealand, United States Security Treaty) ally New Zealand was also in large part motivated by sending signals to Washington's Scandinavian allies, some of whom at the time were flirting with anti-nuclear initiatives. ${ }^{5}$ However, the institutional and geostrategic context of US alliances in Europe and the Asia-Pacific was sharply different during the Cold War, as was their manner of engagement on questions of escalation and nuclear strategy.

2 'Remarks by President Biden at the 2021 Virtual Munich Security Conference', The White House, 19 February 2021, www.whitehouse.gov/briefing-room/speeches-remarks/2021/02/19/ remarks-by-president-biden-at-the-2021-virtual-munich-security-conference/.

3 Brad Roberts, On Theories of Victory, Red and Blue, Livermore Papers on Global Security No. 7, Lawrence Livermore National Laboratory Center for Global Security Research, June 2020, cgsr.llnl.gov/content/assets/docs/CGSR-LivermorePaper7.pdf.

4 David Jones, 'Post-INF Treaty Attitudes in East Asia', Asian Survey 30(5), 1990, 483, doi.org/10.2307/2644840.

5 Stephan Frühling, "Key to the Defense of the Free World”: The Past, Present and Future Relevance of NATO for US Allies in the Asia-Pacific', Journal of Transatlantic Studies 17(4), 2019, 246, doi.org/10.1057/s42738-019-00014-0. 
Today, these differences are far less pronounced, and the US, its Indo-Pacific allies and NATO are rediscovering the political-military challenges of escalation management at the same time. In the context of China's rise, North Korea's nuclear tests and the US retirement of its nuclear-armed, submarine-launched cruise missiles in the 2010 Nuclear Posture Review, Japan and South Korea pressed US officials for 'more NATO-like' extended deterrence arrangements. ${ }^{6}$ NATO allies, for their part, increasingly recognise the relevance for their alliance of a possible conflict with China. ${ }^{7}$ For several years, NATO's institutional architecture has been explicitly drawn on by Japanese security analysts to support proposals to strengthen nuclear deterrence and reassurance in the US-Japan alliance. ${ }^{8}$ Even in Australia, former prime minister Kevin Rudd-whose government in 2008 co-sponsored the Australian-Japanese International Commission on Nuclear Non-Proliferation and Disarmament-joined calls in 2021 for an 'Asian Nuclear Planning Group' that would allow the US, Australia, Japan and South Korea 'to discuss specific policies associated with US nuclear forces and conduct war games and exercises, including those involving the highest political-level participation'?

\section{The Challenge for Australia}

Of all the countries represented in this book, the challenge of how to manage escalation and the role of nuclear weapons in the US alliance is perhaps the greatest for Australia. This is because its engagement with US nuclear deterrence has diverged significantly from that of other Cold War allies. Canberra and Washington have been content since the late 1960s with keeping a low profile for nuclear weapons in the alliance, and the direct defence of Australia has never been a focal point of the alliance. In addition, Australia was only geographically relevant for US nuclear operations through the joint facilities. Australia, therefore, has little

6 See Brad Roberts, The Case for US Nuclear Weapons in the 21st Century (Stanford: Stanford University Press, 2015), Chapter 7, doi.org/10.1515/9780804797153.

7 Hans Binnendijk and Sarah Kirchberger, The China Plan: A Transatlantic Blueprint for Strategic Competition, Atlantic Council, Scowcroft Center, March 2021, www.atlanticcouncil.org/wp-content/ uploads/2021/03/The-China-Plan-A-Transatlantic-Blueprint.pdf.

8 Michito Tsuruoka, Why the NATO Nuclear Debate is Relevant to Japan and Vice Versa (Washington: German Marshall Fund of the United States, 2015).

9 Preventing Nuclear Proliferation and Reassuring America's Allies: Task Force Report, The Chicago Council on Global Affairs, February 2021, www.thechicagocouncil.org/sites/default/files/2021-02/ report_preventing-nuclear-proliferation-reassuring-americas-allies_0.pdf. 
experience of how to approach the questions touched on in this book, even as it now faces a region where the possibility of a great power conflict is far more plausible than in the past, and which, in the words of the 2020 Defence Strategic Update, 'is in the midst of the most consequential strategic realignment since the Second World War'. ${ }^{10}$

Only once did public US-Australian statements in recent years address the operation of the ANZUS Treaty in a 'hypothetical' situation-when Australia and the US agreed in 2011 that a future cyber attack may constitute grounds for invoking its mutual assistance clause. In August 2019, when the US withdrew from the INF Treaty, comments by US Secretary of Defense Mark Esper prior to the 2019 Australia-US ministerial consultations meeting that he would like the US to deploy new land-based, intermediate-range missiles in Asia 'sooner rather than later' took many observers in Australia by surprise. ${ }^{11}$ Even though the Biden administration's commitment to once again seek to 'reduce the role of nuclear weapons in [US] national security strategy' ${ }^{12}$ speaks to the preferences of many in the Australian policy community, what Australia might have to do to achieve this goal in a new era of great power competition has yet to be fully addressed in Australia's defence debate, a task that this book seeks to help inform.

\section{Outline of the Book}

This volume brings together contributors from Europe, North-East Asia, the US and Australia to better understand how to manage the array of political-military challenges confronting European and Indo-Pacific policymakers. The authors are drawn from a wide range of backgrounds, with many having had experience in the policy world addressing the very challenges canvassed in this book.

The first part of the book examines nuclear deterrence and strategic stability with a particular emphasis on the US-China relationship. In the past, Beijing has been hampered by capacity and capability constraints in the

10 Department of Defence, 2020 Defence Strategic Update, www1.defence.gov.au/sites/default/ files/2020-11/2020_Defence_Strategic_Update.pdf.

11 Thomas Gibbons-Neff, 'Pentagon Chief in Favor of Deploying US Missiles to Asia', The New York Times, 3 August 2019, www.nytimes.com/2019/08/03/world/asia/us-missiles-asia-esper.html.

12 President Joseph Biden, Interim National Security Strategic Guidance, March 2021, www.whitehouse.gov/wp-content/uploads/2021/03/NSC-1v2.pdf. 
nuclear sphere that have dovetailed with China's overtly defensive nuclear strategy of assured retaliation. ${ }^{13}$ Elbridge Colby, in Chapter 2, discusses the prospect of a coalition between the US and its allies in addressing Chinese aspirations for hegemony in the Indo-Pacific. A range of countries in the region have a strong rationale to focus on their own defence in relation to the People's Liberation Army, but Japan and Australia in particular can make decisive contributions to a US-led 'anti-hegemonic' coalition against China. In Chapter 3, Oriana Skylar Mastro examines the role of nuclear deterrence in the US-China relationship and canvasses potential pathways to escalation and conflict. While high-risk scenarios (e.g. a declaration of independence by Taiwan) in which Beijing employs major levels of force cannot be ruled out, escalatory dynamics will be easier to manage if both sides act incrementally. And although China may choose to target a US ally with nuclear weapons, this is unlikely given Beijing's desire to preserve flexible targeting options against the US, the major political costs that would result and China's widening conventional military options in the Indo-Pacific. In Chapter 4, Jeffrey Larsen compares the Indo-Pacific and European models of nuclear weapons cooperation with the US. Although cooperation in the Indo-Pacific is less structured than the formal NATO model, Washington's goal in both theatres remains that of reassuring US allies. In Chapter 5, Heather Williams evaluates the future of arms control and strategic stability in the Indo-Pacific. She argues that reducing the risk of escalation between the US and China should be an overriding objective and that formalising a strategic relationship between Washington and Beijing is key.

13 Because China does not practise transparency with respect to its nuclear forces, it is difficult to ascertain the number of warheads in the country's arsenal. However, the most authoritative open-source analysis estimates that:

China has produced a stockpile of approximately 350 nuclear warheads, of which roughly 272 are for delivery by more than 240 operational land-based ballistic missiles, 48 sea-based ballistic missiles, and 20 nuclear gravity bombs assigned to bombers. The remaining 78 warheads are intended to arm additional land- and sea-based missiles that are in the process of being fielded.

Hans Kristensen and Matt Korda, 'Chinese Nuclear Forces, 2020', Bulletin of the Atomic Scientists 76(6), 2020, 443, doi.org/10.1080/00963402.2020.1846432.

Yet, revelations in June and July 2021 that China was constructing a significant number of new nuclear missile silos raised the prospect that Beijing is undertaking a significant expansion of its nuclear weapons force. See William Broad and David Sanger, 'A 2nd New Nuclear Missile Base for China, and Many Questions About Strategy', The New York Times, 26 July 2021, www.nytimes.com/2021/07/26/us/politics/china-nuclear-weapons.html. 
In Part II, contributors explore how alliances in Europe and across the Indo-Pacific manage the political, financial, and material costs and benefits of peacetime deterrence and wartime strategies. This section focuses on how-or indeed, whether-US allies plan for escalation scenarios. In Chapter 6, Sten Rynning examines how NATO has sought to manage deterrence and escalation strategies. He maintains that military planners have struggled with somewhat incoherent messaging at the political level. Seukhoon Paul Choi, in Chapter 7, investigates the US - Republic of Korea alliance and concludes that it has become increasingly complex due to challenges from an assertive China and growing North Korean capabilities, including in the nuclear domain. Choi argues that Seoul and Washington must focus on how they intend to manage the deterrence challenges from Beijing and Pyongyang within the framework of the alliance. In Chapter 8, Tomohiko Satake considers the state of the US-Japan alliance and argues that, in spite of Japan's growing threat environment, and notwithstanding the Abe government's at times assertive rhetoric, recent Japanese governments have taken their cue from public opinion and have continued to be incremental in their approach to the alliance. Brendan Sargeant, in Chapter 9, discusses the US-Australia alliance with a specific focus on the alliance management challenges Australia confronts, which include how Canberra would respond to a major regional crisis involving the US and China. It is important in this respect for senior political leaders to engage more deeply in strategic-level aspects of the alliance to complement the operational level of military-to-military cooperation.

Part III turns to the role of nuclear weapons as well as the impact of new technologies on alliance cooperation and strategic stability in Europe and the Indo-Pacific. Each alliance is distinctive with respect to nuclear cooperation, but one dimension overdue for analysis is whether there is scope for Indo-Pacific allies to emulate NATO arrangements on nuclear sharing, or at least closer allied support for US nuclear operations in the region. Great power competition and conflict also play out across a host of new technologies including cyber, space, missile defence and hypersonics, which has led to resurgent interest in low-yield warheads and intermediate-range missiles. In Chapter 10, Łukasz Kulesa assesses the continuing impact on NATO of new and emerging technologies and the relationship between these technologies and the alliance's evolving nuclear posture. Kulesa argues that NATO must move quickly to adapt in light of the growing challenge from Russia, including its 
integration of cutting-edge technologies into its nuclear and conventional forces mix. Alexander Mattelaer, in Chapter 11, examines NATO's nuclear-sharing arrangements and its identity as a nuclear alliance. Mattelaer maintains that the core function of NATO nuclear sharing is to reinforce alliance political cohesion and notes the potential benefits of greater consultation between the US and its Indo-Pacific allies on nuclear matters. In Chapter 12, Michito Tsuruoka considers the role of US nuclear weapons in North-East Asian alliances and pinpoints scope for closer cooperation between the US and its allies. In particular, Tsuruoka focuses on replicating some of the 'physical' characteristics of the NATO model, such as joint training with US strategic bombers and greater allied involvement in missile defence. In Chapter 13, Masashi Murano examines the relationship between new military capabilities and deterrence architecture in North-East Asia. These capabilities present new opportunities for the US and its allies, but there must be a greater effort at joint integration and coordination to counter Chinese and North Korean threats. Andrew Davies, in Chapter 14, provides an analysis of the major new technological challenges confronting Australian strategic planners. Long protected by geographical isolation, Australia can no longer bank on its physical location as a multiplier of security in an era of accelerating cyber and hypersonic missile threats.

The final part of the book examines the public discourse about nuclear weapons and deterrence. In democratic societies, maintaining public support—or, at the very least, tolerance — of the role of nuclear weapons in national defence is crucial for allies and the US alike. Despite decades of support demonstrated by US and allied governments for nuclear weapons in their alliances, the legitimacy of nuclear weapons and deterrence remains under challenge. In Chapter 15, Michael Rühle considers the role of nuclear weapons in NATO and argues that, despite the best efforts of TPNW advocates, the alliance's nuclear arrangements remain as important as ever to alliance solidarity in a period of renewed Russian assertiveness. Tanya Ogilvie-White, in Chapter 16, assesses the 'legitimacy' challenges to Australia posed by its deterrence and disarmament policies. Surging support for the TPNW among non-governmental organisations and sections of the general public has raised questions about the sustainability of Australia's dual commitment to extended nuclear deterrence and nuclear disarmament and requires a more open public debate about the tensions inherent in this commitment. In Chapter 17, Brad Roberts presents the case for a proactive 'campaign' on the part of 
deterrence advocates aimed at articulating the moral case for nuclear weapons and deterrence. This necessitates greater engagement in dialogue with advocates of disarmament and a more nuanced attempt to shape the discourse over nuclear weapons.

As the contributors to this volume illustrate, greater focus on the relationship between nuclear weapons, deterrence and escalation in Europe and the Indo-Pacific alliances is overdue. The risks of armed conflict during periods of intensifying great power competition are well documented throughout history and are higher today than at any time since the end of the Cold War. Major war between the great powers would almost certainly involve threats to employ nuclear weapons and likely witness the actual use of nuclear weapons as a result of deliberate choices, accident or inadvertent escalation. US allies would be central players in any such conflict, and successful deterrence-including through the threat of use of US nuclear weapons-is a shared allied responsibility. Therefore, grasping the challenges surrounding deterrence and escalation is a necessary prerequisite to formulating policy responses that will stand the test of time. 
This text is taken from Alliances, Nuclear Weapons and Escalation: Managing Deterrence in the 21st Century, edited by Stephan Frühling and Andrew O'Neil, published 2021 by ANU Press, The Australian National University, Canberra, Australia.

doi.org/10.22459/ANWE.2021.01 